\title{
Teaching Exploration and Practice of Software Development Course Based on "Project Experience Learning Mode"
}

\author{
Zou Qingyu ${ }^{1, a}$ and Liu Yan ${ }^{1, b^{*}}$ \\ ${ }^{1}$ College of Electrical and Information Engineering of Beihua University, Jilin, China \\ azouqingyu2002@126.com, b6925897@qq.com
}

\section{Keywords: Software development; Project experience; VC ++ programming}

\begin{abstract}
Software development is an important part of software engineering. In this paper, we puts forward the teaching method of software development course based on "project experience learning mode" for the shortcomings of practical training conditions and practical experience of applied undergraduate colleges. We apply this method to $\mathrm{VC}++$ programming course, and achieved good teaching effect.
\end{abstract}

\section{Introduction}

Software development is the core of software engineering. With the improvement of the degree of the national economy information, the training of software development technicians has been paid more and more attention. In recent years, many colleges and universities have reformed and innovated the teaching mode of software development talents, and used the new teaching methods such as project-driven teaching method, case teaching method and turn-on classroom teaching method for software development course. These methods have gradually changed the traditional teaching mode with a lot of basic theory and a small amount of machine experiment as the main structure, which has played a significant role in improving students' learning enthusiasm, practical ability and innovation ability. Reforming the software training mode of software development has become an important task of the current teaching reform and development of software development courses. In this paper, we introduced the project experience learning model for software development courses. This model is based on project-driven teaching method and experiential learning method, and combined with flip classroom teaching method and MOOC teaching method. We applied the teaching model to the teaching process of "VC ++ programming" course. The results show that this model can greatly enhance the familiarity of corporate and engineering tasks[1-5].

\section{Subject Teaching Method in "Project Experience Learning Mode"}

\section{School and enterprise joint teaching method}

School-enterprise co-cultivation of applied talents is the enterprise into the elements of personnel training system. It converts the traditional theoretical teaching characterized by the disciplinary system to the combination model of theoretical teaching and enterprise practice. It is one of the new ways to reform the personnel training mode in engineering colleges. It is conducive to changing the status of individual education undergraduate education, to solve the diversification of engineering colleges, personalized personnel training. The key problem of the joint training between enterprises and enterprises is that the engineering colleges and universities must make extensive use of the technical, market and practical ability of the enterprises to redesign the curriculum system, update the teaching content, reorganize the teaching activities and innovate the teaching management mechanism. At the same time, engineering colleges should also take the initiative to adapt to the needs of cooperative enterprises, to play their own advantages and professional characteristics to provide multi-dimensional, effective service, the establishment of "win-win" school-enterprise cooperative education operation mechanism. From the perspective of corporate interests, business and university personnel training 
cooperation, runs through the pursuit of their own interests. Constructing scientific and reasonable teaching system and standardizing its operation and management is the key to effectively guarantee the quality of school and enterprise personnel training[6].

\section{Project-driven teaching method}

Project-driven method is derived from the constructivist learning theory. It is made by the famous Swiss psychologist Piaget. The method is based on a project as the main line in the teaching process, and the relevant knowledge points into the various aspects of the project. It extends the breadth and depth of knowledge by deepening or expanding the problem until a complete project solution is obtained. The hierarchical project-driven method is based on the project-driven, from the students' knowledge base, learning ability and learning conditions of reality, in the teaching objectives, teaching content, project tasks and other aspects of hierarchy, in different stages of teaching In order to achieve different levels of teaching objectives and the use of non-hierarchical project tasks, so that the project and the teaching objectives of organic integration. This approach changes the traditional teacher-led project development model to student-led project development model. In teaching emphasis on task-driven, and in the study of emphasis on self-learning[1].

\section{Experiential learning}

Experiential learning regards learning as an experience, and transform and create knowledge during the experiential process. It is a kind of learning style developed for the characteristics of modern work, based on modern educational theory, absorbing educational psychology, management psychology and organizational behavior and other related disciplines. Its educational philosophy and theoretical structure is the integration of educator Dewey's "doing middle school", social psychologist David Cooper's "experiential learning circle", cognitive psychologist Piaget's "epistemology" and Other scholars of the theory and the formation of the learning framework. Experiential teaching focuses on providing learners with real or simulated contexts and activities. The difference between experiential teaching and traditional teaching style is that the former is to let the students "do", the latter is to let students "watch"[2, $3]$.

\section{The Application of "VC ++ Programming" Course}

Visual $\mathrm{C}++$ is a powerful visualization application design language, which widely used $\mathrm{C}++$ development environment based on Windows platform. It is a kind of high development efficiency of high-level programming languages to develop windows applications because of supporting object oriented programming method and MFC class library programming. It is necessary for offering VC++ course in relevant specialities of higher education. Students could improve the professional ability by means of mastering $\mathrm{VC}++$ language grammar knowledge and programming skills. By studying and practicing $\mathrm{VC}++$ program design course, students not only could use $\mathrm{C}++$ language skillfully to compile program code on Windows platform and Visual $\mathrm{C}++$ visualization development environment, but also could have the thought of software engineering with the implementation of comprehensive and high complexity of the basic professional skills required for a software development project. Project experience learning model is divided into five levels.

Level 1. Teachers according to VC++ programming courses in the student's professional curriculum system in the role of the relevant project topics and task requirements. Students are free to group and understand and analyze the project requirements to generate a system design document. The document clearly lists the large functional modules of the system, the functional modules of the large functional modules, and the design of the software system, including the basic processing flow of the system, the organizational structure of the system, the division of modules, the function allocation, the interface design, Operational design, data structure design and error handling design, etc., should ensure that the software requirements are fully assigned to the entire software, according to the system design report encoding.

Level 2: VC ++ programming courses theory to explain the course in accordance with the module to explain the main principles of the module, the basic use of methods and extended learning methods. In 
the classroom teaching process, teachers should interact with students as much as possible to inspire students to think about a certain knowledge point, to stimulate their self-discovery, self-learning ability. In the actual teaching process, by explaining the experiment with each other, to deepen students' understanding of the actual project development process.

Level 3: The experimental process is closely linked to the project. Students in accordance with the "Software System Design Report" on the data structure, algorithm analysis and module implementation and other aspects of the design requirements, the specific preparation of the program work. Through the realization of the module function corresponding to the experimental content, in order to achieve the target system of low-level functions, performance, interface, interface and other requirements, complete the project software, the overall framework and basic functions.

Level 4: In the software high-level functional coding stage, students use the centralized internship period, in the experimental results on the basis of the realization of all the functions of the module, in order to achieve the target system functions, performance, interface, interface and other requirements. After the software program is written, it should be tested. Testing is also a very important step in project development.

Level 5: After the project is completed, the project team will explain and demonstrate the project. The project is subject to acceptance and project analysis by the teacher. The project analysis is based on the project structure, and the functional module is used to guide the field programming. In the implementation of the project analysis process, both to enable students to accept, but also to enable students to learn knowledge.

\section{Summary}

We implemented the hierarchical level project-driven teaching method in $\mathrm{VC}++$ program design course. The number of students in this class is 76 , which is divided into 13 project teams, each project team has 6 students. All of 13 teams can be completed the low-level function of their project and the completion rate no more than 95 percent. But most of the teams were not fully complete the high-level function of project from the perspective of the result of test. The stability of the softwares are slightly insufficient. It means that more than 90 percent students have mastered the basic way of using the VC++ program, comprehended the framework structure of MFC and design thinking, and could solve the problem of general application take advantage of $\mathrm{VC}++$ program. More than 50 percent of the students have been able to flexible use MFC to solve the problem of complex applications. Project experiential teaching method is a new teaching method. It effectively improves the traditional teaching methods, the school and the advantages of combining enterprises, so that students can better grasp the various knowledge and skills.

\section{Acknowledgement}

This work is supported partially by the Key Education Research Project of Beihua university, partially by the Jilin Province Science and Technology Development Project(Grant NO. 20170520057JH), partially by the Beihua University Dr. Scientific Research Fund (Grant NO. 199500103), partially by the university-enterprise cooperation comprehensive reform project of intelligent information processing and networking professionals (Grant NO. SJXQ004).

\section{References}

[1] Eaton, E. Teaching Integrated AI Through Interdisciplinary Project-Driven Courses. Ai Mag, 2017, 38(2): 13-21.

[2] Holmqvist, M. Experiential learning processes of exploitation and exploration within and between organizations: An empirical study of product development. Organization Science, 2004, 15(1): 70-81. 
[3] Kolb, A. Y. and Kolb, D. A. Learning styles and learning spaces: Enhancing experiential learning in higher education. Academy of Management Learning \& Education, 2005, 4(2): 193-212.

[4] Mills, R. J., Hauser, K. and Pratt, J. A. A software development capstone course and project for CIS majors. J Comput Inform Syst, 2008, 48(4): 1-14.

[5] Minocha, S., Petre, M. and Roberts, D. Using wikis to simulate distributed requirements development in a software engineering course. International Journal of Engineering Education, 2008, 24(4): 689-704.

[6] Marr, L. SUNDAY SCHOOL TEACHING - A WOMENS ENTERPRISE - A CASE-STUDY FROM THE CANADIAN METHODIST, PRESBYTERIAN AND UNITED CHURCH TRADITION 1919-1939. Histoire Sociale-Social History, 1993, 26(52): 329-344. 